\title{
Master-Slave Dialectic and Mimicry: A Postcolonial Analysis of the Subjectivity of Frankenstein and his Monster in Mary Shelley's Frankenstein
}

\author{
Dr. Hemangi Bhagwat \& Tanya D'souza
}

\begin{abstract}
The central premise of this paper is to examine how Mary Shelley's Frankenstein enacts the interminable master-slave dialectic. It will begin by temporally locating Frankenstein within the historical context of slavery, imperialism, and racism embroiled within Mary Shelley's nineteenth-century British society. While doing so, it will mainly uncover the racial stereotypes, Manichean binaries and colonial anxieties embedded within Frankenstein and the characters' perceptions of the Creature. The paper will then investigate how the master-slave dialectic is played out through the republican framework of the novel. It will undertake a contrasting analysis of the dialectic as propounded by Hegel and revisioned by Fanon. It will mainly examine Fanon's postcolonial revisioning of the Hegelian dialectic to understand how it enhances and limits the subjectivity of Frankenstein and the Creature. To arrive at a better understanding of this dialectic, the second half of this paper will analyse how Bhabha's concept of mimicry can be used as a tool to study the mechanisms used by Frankenstein's Creature to negotiate his position within the spaces inhabited by his master and protectors. It will unpack how the education which the Creature accesses, is responsible for his ability to mimic, manipulate and revolt against his master. In conclusion, the paper will attempt to understand the result of the interminable revolt between Frankenstein and the Creature who oscillate between both the extremes of the master-slave dialectic.
\end{abstract}

Keywords: Postcolonial, Master, Slave, Race, Mimicry.

In her article "Three Women's Texts and a Critique of Imperialism", Spivak states that in Frankenstein "the language of racism - the dark side of imperialism understood as social mission - combines with the hysteria of masculism into the idiom of (the withdrawal of) sexual reproduction rather than subject-constitution" (1985, p. 255). While one of the tropes in Mary Shelley's Frankenstein is sexual reproduction, the narrative is centrally about the subjectivities of Frankenstein and his Monster which are modelled on the racial prejudices prevalent in the post-abolitionist, imperial British society of the nineteenth century. The narrative stages a constant juxtaposition of the conflicting desires of Frankenstein and his Creature, whose subjectivities oscillate between the different extremes of the master-slave dialectic. In his article "Frankenstein and Slave Narrative: Race, Revulsion and Radical Revolution", Alan M. S. J. Coffee rightly points out that in Frankenstein, Shelley "works perceptively and innovatively within the logic of the master and slave dynamic, showing how their fates are bound up with one another, and the way in which the depravity of the one 
corrupts the virtue of the other" (Coffee, 2019, p. 2). This paper focuses on studying the master-slave dialectic between Frankenstein and his Creature to understand their subjectivities. It will begin by contextualizing Frankenstein within the slavery debates of Shelley's nineteenth-century imperial British society.

\section{Slavery and Mary Shelley's Frankenstein}

"Mary Shelley's youth, her education, and the creation and revision of Frankenstein coincided with the great wave of British antislavery agitation" (Smith, 2004, p. 209). The British transatlantic slave trade was legally abolished in 1807; and in 1833, slave emancipation took place in the British colonies. Mary Shelley published three editions of Frankenstein - a three-volume edition in 1818, a two-volume edition in 1823 and a onevolume, revised and widely reprinted edition in 1831 (Malchow, 1993, p. 120). Malchow notes that Shelley created the plot of Frankenstein in an attempt to produce a ghost story - as an unmarried, eighteen-year-old, she accepted the challenge of her friends during a house party, near Geneva, in June 1816 (1993, pp. 100-2). The composition of Frankenstein was, however, inevitably influenced by both the sides of the slavery debates of its milieu.

As Smith notes, "[i] ssues of race and slavery were central to the emergent English culture with which Mary Shelley eagerly engaged" (2004, p. 209). She together with her father William Godwin demonstrated concern with the issue of British transatlantic slave trade and chose to side with the abolitionists (Sawyer, 2007, pp. 20-21). In Political Justice, Godwin denied the notion that climate impacts human characteristics and disapproved prejudices which claimed that a person's race determines their ability to reason or to be educated. He, however, accepted certain racial stereotypes that "Negroes reached sexual maturity earlier [and] had a more passionate temperament than Europeans" (Malchow, 1993, p. 95). Shelley seems to inhabit the same mindset as her father, Godwin. As observed in her journal, she boycotted sugar products because they were manufactured by slave labour, yet she read Bryan Edwards' The History, Civil and Commercial of the British Colonies in the West Indies which portrayed slaves stereotypically. Sawyer states that "Mary was fascinated by the book, perhaps because she always sympathized with marginalized and oppressed characters" (2007, p. 21). Yet, nuances of such racial stereotypes are constantly projected in the narrative of Frankenstein. This projection itself, however, allows for critical contestation.

According to Paul Gilroy, in the emergent English culture which Shelley belonged to, "the moral and political problem of slavery looms large... [because] [n]otions of the primitive and the civilised which had been integral to pre-modern understanding of 'ethnic' difference became fundamental cognitive and aesthetic markers in the processes which generated a constellation of subject positions..." (as cited in Smith, 2004, p. 209). The narrative of Frankenstein draws on these aesthetic markers which define the characters' subjectivities and perceptions-they belie the ethnic differences and racial prejudices that created them.

\section{Manichean Aesthetics and Subjectivity}

Elizabeth Bohls argues that Frankenstein "indicts aesthetics as an inherently imperial discourse, structured by principles of hierarchy and exclusion... [it] binds together a little community, a microcosm of polite British society, marred by its... colonization of nonEuropean peoples" (as cited in Smith, 2004, p. 217). The prejudices of the characters in Frankenstein is based on the Manichean binaries of imperial ideology which polarize "the 


\section{Master-Slave Dialectic and Mimicry: A Postcolonial Analysis of the Subjectivity of Frankenstein and his Monster in Mary Shelley's Frankenstein}

society, culture and very being of the colonizer and colonized into the Manichean categories of good and evil. The world at the boundaries of civilization is perceived as uncontrollable, chaotic, unattainable and ultimately evil, while the civilized culture is the embodiment of good" (Ashcroft, et al., 1998, p. 134). In the Manichean sense, "all that is light is orderly, tractable, rational, angelic and ultimately good; whereas all that is dark is degenerate, chaotic, transgressive, lunatic, satanic and hence evil" (McLeod, 2012, pp. 155-56). Right from the beginning of Frankenstein, the Manichean mindset of the characters is evident-not only in their perception of the Creature but also in their approach towards people in the margins of society and those whose appearance challenges aesthetic ideals of beauty.

Mellor indicates that at the very start of the narrative the racial differences are pronounced when Walton perceives the Creature and defines him as "a savage inhabitant of some undiscovered island" as compared to the "European" (Shelley, 2004, p. 11). Victor Frankenstein. Frankenstein's mother, Caroline Beaufort chooses to adopt Elizabeth Lavenza because she appeared "fairer than a garden rose among dark-leaved brambles" (Shelley, 2004, p. 23). Elizabeth - born to a Milanese nobleman and his German wife-was an orphan child living with her foster parents in the cottage of a poor Italian peasant. Smith indicates that "Mary Shelley's 1831 revisions [of Frankenstein] intensified Elizabeth's Saxon racial features as the flower of white girlhood, contrasting with the other children" (2004, p. 217). Frankenstein's mother chose her among the five hungry children of the peasant because she was "a distinct species, a being heaven-sent, and bearing a celestial stamp in all her features" while "[t]he four others were dark-eyed, hardy little vagrants." (Shelley, 2004, p. 22) Like her mother, Elizabeth grows to absorb this Manichean dualism in her perception of society. In her first letter to Frankenstein, she communicates gossip of the neighbourhood by relating the marriages of two sisters - "[t]he pretty Miss. Mansfield" and "[h]er ugly sister, Manon" (Shelley, 2004, p. 57). While both the women were married successfully, the need for Elizabeth to refer to them based on their aesthetic differences seems to be an inevitable habit.

Victor Frankenstein perceives the "hired nurse, the wife of one of the turnkeys" during his imprisonment - he was suspected for his friend Henry Clerval's murder - with the same Manichean delirium coupled with a Marxist superiority. In his eyes, the nurse's "countenance expressed all those bad qualities which often characterise that class... the expression of brutality was strongly marked in [her] visage" (Shelley, 2004, pp. 178-79). Only the magistrate, Mr. Kirwin, who was educated and in the higher realms of the class hierarchy, displayed "extreme kindness" towards Frankenstein and undoubtedly "[h]is countenance expressed sympathy and compassion" (Shelley, 2004, pp. 180). Frankenstein, however, used Manichean yardsticks to judge even the educated professors at the University of Ingolstadt. Since "M. Krempe was a little squat man, with a gruff voice and a repulsive countenance", Frankenstein was unable to like his subject or bring himself to attend his lectures on Natural Philosophy. He could not bear to "hear that little conceited fellow deliver sentences out of a pulpit". Instead, he attended the Chemistry lectures of M. Waldman who possessed "an aspect expressive of the greatest benevolence" (Shelley, 2004, pp. 35-36). and the sweetest voice Frankenstein had ever heard. This Manichean and racially prejudiced mindset of the characters in Frankenstein indicates how their perception of Frankenstein's Monster could only serve to magnify and highlight the same stereotypical gaze.

\section{Stereotypes and Racial Prejudice}

Rosemary Jackson argues that "The monster is Frankenstein's lost selves, pieces of himself from which he has been severed, and with which he seeks re-unification, hence his reluctance 
to kill it" (as cited in Smith, 2004, p. 219). Contrary to her statement, a postcolonial analysis of Shelley's text reveals Frankenstein's Monster to be a subject whom Frankenstein initially ignores and ultimately rebels against. If the Monster is perceived as pieces of Frankenstein's lost selves, then these pieces are his racist prejudices which the Monster's corporality made apparent. The Creature's physiognomy goes one step beyond that of a real slave; it turns racial prejudice inside-out, enforcing Frankenstein to acknowledge a painful, almost impossible confrontation. In other words, the Monster's corporeal body constituted for Frankenstein a site which reflected his own racially prejudiced selves. Since he created the Monster larger than the average human size, the prejudices threatened to confront him in such a magnified vein that he is unable to confront him - he can only ignore or rebel him; he can only take flight or fight him, he cannot accept his subjectivity. The Creature's remarkably huge size serves to not only magnify Frankenstein's prejudices but also to represent racial stereotypes generally held against slaves in the British West Indies colonies.

Since "the minuteness of the parts formed a great hindrance" to Frankenstein's speed while creating the Monster, he made "the being of a gigantic stature... about eight feet in height, and proportionally large" (Shelley, 2004, p. 43). In Bryan Edwards' history of slavery, the Mandingoes are described as "remarkably tall" (as cited in Sawyer, 2007, p. 22)and agile. Shelley was certainly influenced by these descriptions while composing the Creature in her novel. Sawyer notes that the Creature's agility is evident in his "superhuman speed", which allows him to run with the "swiftness of lightning" (as cited in Sawyer, 2007, p. 22). He also inhabits animalistic and ape-like qualities - "to scamper up summits and spring out of windows", to "withstand extremes of temperature that would kill a white European"-which were another racial stereotype. "[T] he monster's savage strength is obvious in his bare-handed strangling of William, Henry and Elizabeth, a kind of murder anecdotally attributed to runaway slaves who often had no means to procure sophisticated weapons of any sort" (Sawyer, 2007, p. 22).

The Creature's facial features and complexion are also similar to African slaves- he has "lustrous black" hair and "straight black lips" (Shelley, 2004, p. 47). Malchow notes that his skin colour was like mummies who are "ordinarily dark brown or black in colour" (1993, p. 103). The Creature is also described as having "dull yellow... watery eyes" and "yellow skin" (Shelley, 2004, p. 47). In his history of slavery, Bryan Edwards described the Eboes as "sickly yellow in complexion with eyes that appeared to be "suffused with bile"" (as cited in Malchow, 1993, p. 103). Malchow, however, adds that Mary Shelley did not intend to "create a specifically Negro monster". Since the narrative originated from her eighteen-year-old mind, she drew on childhood fantasy and "dredged up a bogyman... constructed out of a cultural tradition of the threatening "Other" ... from the dark inner recesses of xenophobic fear and loathing" (1993, p. 103). Sawyer's comment adds to the understanding of this xenophobic fear. He states that the Creature's features "reflect the contemporary accounts of the so-called "deformities" [sic] of some natives, accounts that also produced a fear of mongrelisation of whites due to interracial marriages... often these marriages were denounced for producing "monstrously" mixed-race children" (2007, p. 22).

The large proportions and agility of the Creature draw on two more racial stereotypes: early sexual maturity, and passionate temperament-stereotypes accepted by Godwin. Edward Long, a racist propagandist for slavery argued that "the Negro" was "libidinous" and possessed "unusually large genitalia" (as cited in Malchow, 1993, pp. 111). Godwin also admitted that the hot climate caused Negroes to reach sexual maturity earlier. These stereotypes generated colonial anxiety among the Britishers. Malchow argues that Elizabeth's murder draws on this sexual threat of the black slaves - " $[\mathrm{t}]$ he threat that white women might be brutalized by over-sexed black men of great strength and size became a cliché of racist 


\section{Master-Slave Dialectic and Mimicry: A Postcolonial Analysis of the Subjectivity of Frankenstein and his Monster in Mary Shelley's Frankenstein}

writing" (1993, pp. 112). Hence, the contrast between Elizabeth and the Monster is made starker by Shelley in her 1831 revision of Frankenstein where Elizabeth's "stereotypically northern, Teutonic beauty" (Malchow, 1993, p. 112). is highlighted. Here, the Manichean binaries serve to reinforce the racist stereotypes. (see subsection no. 2 of this paper) Malchow points out how Elizabeth is presented as the "master-race maiden whom the Monster-her racial negative... violently assaults in her bedroom and strangles... The scene is emotionally and suggestively that of rape as well as murder..." (1993, pp. 112-13). Gilbert and Gubar also noted the Monster's desire for Justine as resonating with a "sinister rape fantasy" (as cited in Smith, 2004, p. 217)

Smith points out that the Creature's passionate temperament springs from the prejudices emerging from slave insurrection in the aftermath of the French Revolution. He indicates how after the De Laceys shunned the Creature; he seeks revenge by "burning the house in insurrectionary fashion" (2004, p. 213). The repetitive murders he commits-he kills William, Clerval and Elizabeth-due to the injustice levied on him by Frankenstein and the members of his imperial society portray his revengeful passions again. His passionate emotions are witnessed even in the end of the narrative when he weeps over Frankenstein's dead body - Walton stereotypically defines his features as "instigated by the wildest rage of some uncontrollable passion" (Shelley, 2004, p. 222). These examples show how Shelley endowed her Creature with a dynamic subjectivity, capable of expressing both revenge and grief.

Hence, after basing the narrative on contemporary stereotypes, Shelley goes on to contradict them. Like her father, she was influenced by both sides of the slavery debate - her Creature is endowed with racial stereotypes and the ability to rebel against his master, Frankenstein. In doing so, she makes the readers both fear and sympathize with the Creature. It made her text relatable to the contemporary audience who feared or hoped for the abolition of slavery (Malchow, 1993, p. 90). Smith rightly opines that "Shelley... might be seen to be presenting both sides of the issue: sympathetic to the Monster, but also registering shock and horror at his however justifiable excesses" (2004, p. 218). The Monster's speech mobilizes empathy, while his strength and agility enable him to murder others and evade the same himself. The shock towards the Creature's violence can be registered in Elizabeth's disbelief in society after William's murder and Frankenstein's reaction to all the three murders. At the same time, the Creature's speech mobilizes Frankenstein's empathy. Their reactions sketch out the reception of contemporary readers in Shelley's society. More importantly, her sympathetic presentation of the Creature is what makes the text and his characterization open for critique. The vivacity of the text and the Creature's subjectivity can be better understood by placing Frankenstein and his Monster within the framework of the master-slave dialectic.

\section{The Master-Slave Dialectic}

Smith asserts that "[t]he intertwining of master and creature echoes Hegel's formulation of the entanglement of mastery and slavery wherein the identity of the master is seen as bound to the consciousness of his slave or bondsman" (2004, p. 216). In Frankenstein, the subjectivity of Frankenstein and his Creature are dependent on each other. From the moment Frankenstein decides to create the Monster until the murder of William, he fails to think of anyone else. He never adopts the actual responsibility of nurturing him; yet, his racist prejudices subject him to perpetual anxiety about the Creature and psychological bondage. After the murder of William, Elizabeth and Clerval, Frankenstein's only motive is to revenge their deaths. He chases the Creature to murder him until his last breath. The Creature, 
likewise, depends on his master, Frankenstein, for recognition. Throughout the narrative, he pleads and rebels against him for recognition-it constitutes the locus of his subjectivity.

Hegel envisions the master-slave dialectic "not only as an intersubjective process, motivated by a desire for recognition by the other, but also as an essentially conflictual one" (Teixeira, 2018, p. 108). Within the dialectic, in other words, both the master and the slave desire to be recognised by the other. In the absence of this mutual recognition, both the subjects will conflict with each other until each is recognized as an independent subject by the other. "[E]ach consciousness strives to assert its self-certainty, initially, through the exclusion and elimination of all that is other" and "seeks the death of the other" (Teixeira, 2018, p. 108) at the risk of its own life. In Frankenstein, the Creature desires to be recognized by his masters - the De Laceys and Frankenstein. He is spurned, however, by both masters and other humans because their colonial, racial and Manichean mindsets fail to accept him as an equal member of their society. Frustrated with their disapproval, he decides to wage war against his masters. He begins first, by burning the De Laceys' house and later, by murdering Frankenstein's close friend and relatives-Henry Clerval, William and Elizabeth. On learning about his Creature's revengeful deeds, Frankenstein also swears to rebel against him. Hence, both decide to rebel against each other until the point of death.

In the conflict that ensues, the subjectivities of the master and slave oscillate to occupy the opposite extreme. The Creature makes this reversal apparent when he addresses Frankenstein by stating, "Slave... [y]ou are my creator, but I am your master; - obey!" (Shelley, 2004, p. 167). Even Frankenstein admits that the Creature "left marks in writing on the barks of the trees, or cut in stone, that guided [him]" (Shelley, 2004, p. 207), while he hunted the Creature to destroy him. In this way, Frankenstein becomes dependent on the Creature for his recognition and the satisfaction of his physical needs. The Creature, on the other hand, becomes aware of his independent self-consciousness by productively labouring with the material world. In other words, during the rebellion between master and slave in Frankenstein, The Creature inhabits the superior role of the master. He beckons Frankenstein by stating: "Come on, my enemy; we have yet to wrestle for our lives" (Shelley, 2004, p. 207). He charts the route for Frankenstein to follow and procures food to reinforce him. Smith notes that "Ultimately... it is [the Creature] who enables and directs Frankenstein's pursuit of him, leaving supplies for his master... [hence, there is] a reversal of the terms of bondage" (2004, p. 216). According to Bugg, he forces his master into exile. He also ensures that Frankenstein reads the language of his exile which he inscribed on stone like a decree (2005, pp. 665-66).

The Creature, however, eludes a perfect placement within Hegel's dialectic. Smith indicates that within Hegel's dialectic " $[\mathrm{t}]$ he bondsman has power over the master by refusing him autonomy and forcing him into psychological dependence. Paradoxically, then, the slave has a greater awareness of freedom, whereas the master is only conscious of his need for control and mastery" (2004, p. 216). While Frankenstein remains conscious of his need to control the Creature until his death, the Creature fails to force him into complete psychological dependence-Frankenstein reaffirms his mastery and justifies his behaviour towards the Creature as righteous till his last breath. In his last speech to Walton, Frankenstein asserts that he feels "justified in desiring the death of [his] adversary" and does not find his "past conduct... blamable" (Shelley, 2004, p. 220). According to Hegel, "The truth of independent consciousness is accordingly the consciousness of the bondsman... Just as lordship showed its essential nature to be the reverse of what it wants to be, so, too, bondage will... change round into real and true independence" (as cited in Smith, 2004, p. 216). Yet, although the Creature appropriates the position of the master during the hunt, he is unable to ever attain true independence. After Frankenstein's death, he fails to even imagine 


\section{Master-Slave Dialectic and Mimicry: A Postcolonial Analysis of the Subjectivity of Frankenstein and his Monster in Mary Shelley's Frankenstein}

living an independent life because his subjectivity is bound to his master. Hence, even after his master's death, the Creature fulfils his master's desire by deciding to self-immolate himself.

"[F]or Hegel, blacks had no history and no true self-consciousness" (Smith, 2004, p. 215). For this reason, Hegel's dialectic fails to accommodate Frankenstein's Creature-he is treated as an African slave throughout the narrative. The Hegelian bondsman needs to recognize himself as an independent self-consciousness by identifying with his creation procured by labouring with the material world. In the case of Frankenstein's Monster, his stay at the hovel adjacent to the De Laceys' residence creates the setting for him to become selfreliant. He procures a light vegetarian diet, assists the De Laceys by collecting firewood and educates himself. With these tools, he independently rebels against his master. Even while Frankenstein hunts him, the Creature determines the route and procures food for his master by labouring with the material world. Yet, he fails to attain true independence. This is because he did not desire to secure recognition through his labour. He wanted to be recognized by his masters, both the De Laceys and Frankenstein. This shows that the sole placement of the subjectivities of Frankenstein and the Creature within the Hegelian masterslave dialectic is limited in scope. It requires applying Fanon's postcolonial revisioning of Hegel's framework.

Fanon stretched Hegel's dialectic to address the colonial issue. He argued that the colonial slave turns away from the object of his creation and moves towards his master for recognition. He then enslaves himself by the prejudices internalized by his master. In Frankenstein, once the Creature educates himself, he chooses to use this newly acquired medium to gain the companionship and protection of the De Laceys whom he looks up to as his superiors. Unable to seek their protection, he turns to his creator and master, Frankenstein. Since Frankenstein is psychologically enslaved to Manichean aesthetics and racist prejudices like the De Laceys, he also shuns the Creature. When Frankenstein disagrees to create a female companion for him, the Creature decides to revenge himself by murdering Clerval and Elizabeth. Consequently, Frankenstein decides to hunt and kill the Creature and an interminable battle between master and slave ensues. The battle exhausts Frankenstein and causes his death. Yet, the Creature fails to rejoice or seek independence. Instead, he decides to commit suicide because his destruction was his master's desire. Hence, even after Frankenstein's death, he clings onto the last remnants of seeking his master's recognition and approval. So, what is the need and consequence of the rebellion, when it ends in death and futility?

\section{The Nineteenth-century Republican Framework}

The need for this battle or rebellion can be understood by placing the master-slave dialectic within the republican framework of the early nineteenth century. In his article "Frankenstein and Slave Narrative: Race, Revulsion and Radical Revolution", Alan M. S. J. Coffee locates the slave narrative in Frankenstein within this republican framework. He describes how the framework was used in the pro-revolutionary thought of the early nineteenth-century American, French and Haitian Revolutions. It gained importance among abolitionists and was used by Mary Wollstonecraft to diagnose the social repercussions of treating women as slaves and to find a path to emancipation.

Coffee indicates that "[f]reedom, equality and virtue as values co-exist in a delicate harmony" (2019, p. 13) within a republican framework. A republican society is based on 
equality and it is devoid of hierarchy. When slavery enters this framework, equality is compromised. The slave embodies the status of a dependent individual with less power. Hence, virtue is corrupted, freedom is compromised and the harmony within the republican framework collapses. A slave society emerges which is characterized by inequality, hierarchy and corruption. Hence, Coffee argues that in Shelley's Frankenstein, "[m]aster and slave" are both "implicated and degraded by their corrupting relationship in equal measure" $(2019, \mathrm{p}$. 14).

In Frankenstein, the republican framework-based on the harmony between freedom, equality and virtue - remained intact until Frankenstein created his Monster. In her first letter to Victor, Elizabeth stated that "[ $\mathrm{t}]$ he republican institutions in [Geneva] have produced... less distinction between the several classes of its inhabitants" (Shelley, 2004, p. 55). Her words connote a certain extent of equality prevalent within the republican framework in the novel. When the Creature is created and enters this framework, however, the harmony within it collapses. On the night when the Creature comes to life, Frankenstein fails to endure the mere sight of him, let alone take responsibility for him. "Unable to endure the aspect of the being [he] had created, [he] rushed out of the room... endeavouring to seek a few moments of forgetfulness" (Shelley, 2004, pp. 47-48). He attempts to forget his very existence, though he cannot bring himself to do so.

Abdul Jan Mohammed explains the consequences of a Manichean mindset on colonial discourse by indicating that "the colonizer's assumption of moral superiority means that 'he will not be inclined to expend any energy in understanding the worthless alterity of the colonized" (as cited in Ashcroft, et al., 1998, p. 134). This assertion, nevertheless, partially contradicts the case of Victor Frankenstein. When the Creature requests him to create a female mate for him on the condition that he "will quit the neighbourhood of man" (Shelley, 2004, p. 145), Frankenstein empathizes with him and expends his energy in creating another Creature. However, he himself forestalls this attempt. Frankenstein destroys the partially created female Creature because his prejudiced subjectivity fears the assumed hypermasculinity and hypersexuality of the Creature and his future mate. Coffee rightly argues that not only the Creature (slave) but even Victor Frankenstein (master) suffers from corruption and becomes a slave to the dialectic. Frankenstein becomes a slave of his internalized racial prejudices which disallow him to live a free life and accept his Creature as an equal. This replaces his virtue for the vice of perpetually achieving mastery over the Creature, even if it involves chasing and murdering him.

Frankenstein subjects the Creature to the same corrupted fate he endures. Zohreh T. Sullivan understands Frankenstein as being a supreme colonizer in all his behaviour towards the colonized, including "denial of subjectivity, and denial of connection or responsibility for the Creature he has tried to make in his own image" (as cited in Sawyer, 2007, p. 25). Frankenstein denies the Creature subjectivity and freedom by robbing his sole chance of solace - a female mate. Thus, he is forced to live a life in the margins of society, devoid of equality and justice. Shelley, however, empowers him with a rebellious subjectivity. Hence, frustrated with the injustice levied on him by Frankenstein, the Creature declares war against him until death. He kills those very close to Frankenstein to avenge himself. Simultaneously, Frankenstein decides to hunt and destroy his Monster until his last breath. Thus, the rebellion between master and slave begins. Coffee validates this rebellion by stating Wollstonecraft's analysis of the French Revolution. Wollstonecraft believed that within a republican framework immediate change through a rebellion is essential to bring an end to the corruption and undertake a gradual rebuilding process. Coffee asserts that the task of orchestrating the rebellion is vividly accomplished by Shelley in Frankenstein (2019, p. 24). 


\section{Master-Slave Dialectic and Mimicry: A Postcolonial Analysis of the Subjectivity of Frankenstein and his Monster in Mary Shelley's Frankenstein}

\section{The Creature's Education and Mimicry}

One of the important tools the Creature uses to rebel against his master is mimicking their manners and behaviour. In Frankenstein, the Creature's mimicry is menacing in the way Bhabha conceptualized the term. When the Creature speaks the language of his master before old De Lacey, Frankenstein and Walton, they all are mesmerized into empathising with his argument and suffering. They experience menace only after his speech ends, and their internalized Manichean and racial prejudices conflate with his rhetoric to define it as manipulative and distrustful.

Winter argues that Shelley gives voice to people in the margins of society, those "defined as alien, inferior or monstrous" (as cited in Smith, 2004, p. 209). The Creature is relegated to the margins of society because Frankenstein denies him subjectivity. But Shelley empowers him with a voice that mobilizes empathy from Frankenstein and reduces him to psychological dependence. For instance, when the Creature requests Frankenstein for a female mate "[h]is words had a strange effect on [Frankenstein]. [He] compassionated him, and sometimes felt a wish to console him; but when [he] looked upon him... [his] feelings were altered to those of horror and hatred" (Shelley, 2004, p.145). Frankenstein experienced both compassion and hatred towards the Creature because his mimicry was menacing for him. The Creature's language — a mimicry of the master's language — reminded Frankenstein of his own language, but his physiognomy reminded him of his internalized Manichean binaries and racial prejudices. To relieve himself of this menace, Frankenstein conflated his internalised prejudices with the Creature's rhetoric and defined it as manipulative and distrustful. Later, Frankenstein warns Walton about the Creature's manipulative powers of speech which he defines as "powers of eloquence and persuasion". That is why, when Walton encounters him mourning over Frankenstein's corpse at the end of the novel, he replaces his feeling of being "at first touched" with "indignation." (Shelley, 2004, p. 224) Besides, Walton's own racial prejudices disallow him to even "raise [his] eyes to [the Creature's] face" more than once (Shelley, 2004, p. 222). The dichotomy between feelings of empathy and those of distrust can be best witnessed when the Creature attempts to seek refuge in the De Laceys cottage. Since old De Lacey is blind and fails to visually perceive the Creature, he empathizes with him. The remaining members of the family are, however, too shocked by his physical appearance which challenges their aesthetic standards of beauty. With feelings of disgust and fear for his father's safety, Felix "darted forward", "tore" (Shelley, 2004, p. 133) the Creature away and violently hit him until he escaped.

After this incident, the Creature's mimicry goes one step beyond menacing - it adopts a rebellious, corporeal character. Malchow rightly asserts that " $[t]$ he monster's thirst for knowledge is in fact a thirst for deliverance from the condition of [slavery]." (Malchow,1993, p. 117) “As Felix reads to Safie from Volney's Ruins of Empire, the Creature acquires a kind of imperial literacy... In his resistant reading of Volney the periphery has moved to the center" (Bugg, 2005, p. 662). He not only reads Volney's text against the grain but also implements active resistance in his life. Once he realizes that mimicking the manners of the masters was unable to secure their protection and assistance, he mimics the governing strategies of mass-murdering and conceit he learnt about through Felix's teaching of Volney's Ruins of Empire. He begins by murdering William and "then causes the judicial murder" (Malchow, 1993, p. 102) of Justine. After Frankenstein absconds from creating a female Creature and decides to get married, he murders Henry Clerval and Elizabeth. In this way, the Creature's resistant reading of Volney equips him to mimic his master and rebel against him. 
Nevertheless, the Creature's education also teaches him self-contempt and ethnic stereotypes. Malchow explains that just as the education offered to the "black or freed slave served merely to reinforce his own awareness of inferiority", so the Creature's education has "taught him self-contempt." (Malchow, 1993, p. 118). His resistant reading of Volney teaches him the imperial "ideology of superiority" where the Occident is a "genius" while the Orient is "slothful." (as cited in Bugg, 2005, p. 662). Hence, the Creature learns to hate himself and attempts to be as productive as possible. He looks up to his masters as superiors till the end of the narrative. They are superior humans whose manners and actions he longs to mimic; without them his existence is futile. As a result, he internalizes his masters' stereotypes and decides to destroy himself through self-immolation, after Frankenstein's death.

\section{Conclusion}

While Frankenstein and his Monster oscillate between embodying the subjectivities of master and slave, the Creature is demonstrated as the true slave at the end of the narrative. The Creature himself makes this claim after Frankenstein's death by stating: "I was the slave, not the master" (Shelley, 2004, p. 223). The fact that he makes this statement in the past tense shows that after his master's death, he is left devoid of any subjectivity or purpose to live for. When Frankenstein dies, he justifies his prejudiced actions as righteous. On the other hand, though the Creature reigns victorious, he is unable to justify his actions. This is because he internalizes the prejudices levied on him by his master and society. Drowned in the rhetoric of self-denial and self-blame, he determines to commit suicide by self-immolation. Nevertheless, as Coffee argues, the rebellion between master and slave demonstrates the corruption of nineteenth-century society and highlights the need for rebuilding.

The task remaining then is to examine whether Shelley also indicates any signs of rebuilding within the society in the novel. Clerval's murder at the hands of the Creature and the death of Walton's dreams symbolised by his unfinished voyage are examples of colonial ventures forestalled and diverted. Besides, the narrative - a vivid embodiment of the rebellion between master and slave-is itself evidence for the need for change and social rebuilding. Fanon argues that the colonial slave is not given the opportunity to rebel because the abolition of slavery was a legal battle fought by the slaveholders. Hence, the colonial slave longs for a chance to rebel. Shelley empowers her slave to rebel and reign as victorious until the very end. All this highlights the importance of the Creature's rebellion.

Kari J. Winter rightly asserts that Shelley gives voice to people in the margins of society (see subsection no. 5 of this paper). The narrative does not even demonstrate the Creature's suicide. Spivak points out that since Walton's sister Mrs. Saville does not close the frame of Shelley's novel the Creature is free to step "beyond the text" (1985, p. 259). Winter believes that since the Creature remains alive even when Frankenstein ends, it leaves the readers "with a faint hope that at some future time he will find a voice and place in the world" (as cited in Smith, 2004, p. 212). Like Godwin, Shelley also believed in the ability of slaves to reason. That is why, her Creature can educate himself, summon empathy, mimic the master and successfully rebel against him. These abilities allow readers like Winter to imagine the Creature finding a voice and place in society. Sawyer delves into the etymology of the word "creature" to learn that Creatures are objects "perpetually becoming created" just like Shelley's Creature and her narrative which are "continually being re-produced in criticism, in stage productions, and in various film versions" (Sawyer, 2007, p. 27). Thus, Shelley's Creature continues to challenge frameworks and critical interpretations, just as he challenges colonial and racial stereotypes. 


\section{References}

Ashcroft, Bill, Gareth Griffiths and Helen Tiffin (Eds.). (1998). Key Concepts in PostColonial Studies. Routledge.

Bugg, J. (2005). "Master of their language": Education and exile in Mary Shelley's Frankenstein. Huntington Library Quarterly, 68(4), 655-666. https://doi.org/10.1525/hlq.2005.68.4.655

Coffee, A. M. S. J. (2019). Frankenstein and Slave Narrative: Race, Revulsion and Radical Revolution. In M. Paradiso-Michau (Ed.), Creolizing Frankenstein (pp. 1-24). Rowman \& Littlefield. https://ssrn.com/abstract=3548595

Malchow, H. L. (1993). Frankenstein's Monster and Images of Race in Nineteenth-Century Britain. Past \& Present, (139), 90-130. https://doi.org/651092

McLeod, John. (2012). Beginning Postcolonialism. Viva Books.

Sawyer, Robert (2007). Mary Shelley and Shakespeare: Monstrous Creations. South Atlantic Review, 72(2), 15-31. https://doi.org/27784706

Shelley, M. (2004). Frankenstein. Wilco Publishing House.

Smith, A. L. (2004). 'This Thing of Darkness': Racial Discourse in Mary Shelley's Frankenstein. Gothic Studies, 6(2), 208-222.

https://search-proquest-com.library.britishcouncil.org.in:4443/docview/216264518

Spivak, G. C. (1985). Three Women's Texts and a Critique of Imperialism. Critical Inquiry, 12(1), 243-261. https://doi.org/1343469

Teixeira, M. (2018). Master-Slave Dialectics (in the Colonies). Krisis: Marx from the Margins: A Collective Project, from A to Z, (2), 108-112.

https://krisis.eu/master-slave-dialectics-of-the-colonies

\section{$\underline{\text { Bio-note }}$}

Dr Hemangi Bhagwat is currently teaching as an Associate Professor and Head in the Department of Business Communication at K. J. Somaiya College of Science and Commerce. She is also an MPhil and PhD Research Guide for the Department of English at the University of Mumbai.

Email: bhagwat_hemangi@yahoo.com

Tanya D'souza has completed M.A. (Honours with Research) in English from University of 
Mumbai in 2016. The title of her M.A. dissertation is "Non duality and Anthropocentrism: An Ecofeminist critique of Chris Wedge's Epic and Robert Stromberg's Maleficent". She is currently pursuing her $\mathrm{PhD}$ in English from University of Mumbai. She was formerly teaching as an Assistant Professor in the Department of Communication at St John College of Humanities and Sciences. Her areas of research-interest are Fantasy, Film studies, Ecofeminism and Postcolonialism.

Email: tanilicious1993@gmail.com 